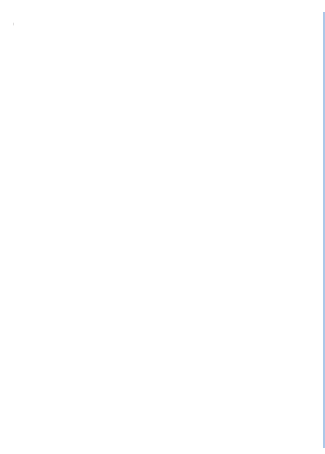

Journal of Geology.

\title{
Peculiarities of Stratigraphic Distribution and Paleoecology of Jurassic Bivalve Mollusks of the Pre-Carpathian Foredeep
}

\author{
Ihor V. Shaynoha, Vasyl V. Karabyn. \\ Ivan Franko National University of Lviv, Lviv, Ukraine. chigvos@ukr.net \\ Lviv State University of Life Safety,Lviv,Ukraine, vasyl.karabun@gmail.com
}

\section{Received: 20.05.2021 \\ Received in revised form: 08.08.2021 \\ Accepted: 04.11.2021}

Abstract. Pre-Carpathian region is one of the oldest oil and gas producing regions of our
country, which is attracting more and more attention of scientists. In the Outer zone of
the Pre-Carpathian Foredeep, Jurassic deposits occur at considerable depths (up to 3,000 $\mathrm{m}$ ), so we obtain almost all geological information about them exclusively during the study of core material selected during drilling. A comprehensive and detailed study of the Jurassic deposits of this zone during exploration drilling in the 1950s contributed to the discovery of the Kokhanivske and Sudovovyshnianske oil deposits and Rudkivske gas deposit, as well as a number of oil and gas manifestations. After that, the interest in the conditions of formation and stratification of Jurassic deposits increased. Researchers have begun to treat them as the promising objects for oil and gas exploration. Jurassic deposits in the Pre-Carpathian Foredeep fill a single depression - the Stryi Jurassic deflection, covered by a thick layer of Cretaceous and Neogene rocks. The study of their geology and stratigraphy has acquired important applied and scientific significance, because stratigraphic research serves as a basis for clarifying the history of geological development of the region, performing tectonic constructions, reconstruction of paleogeographic and paleoecological conditions, comparison of productive horizons and specification of their stratigraphic position, search for new objects promising for hydrocarbons. Extremely rare finds of paleontological remains (which are not always well preserved) do not allow to unambiguously determining the age of the host rocks. It is still not always possible to clearly stratigraphically distinguish and correlate these rocks due to weak paleontological study and partial uncertainty in the interpretation of the geological structure of these strata. Despite the significant amount of research we have done, there are some debatable issues regarding the completeness of the section of these rocks and the presence of separate stratigraphic units in them. For many years, we have studied in detail and comprehensively bivalve mollusks found in the core of wells drilled in the Outer zone of the Pre-Carpathian Foredeep. As a result, the age of the host strata was specified and confirmed, as well as the thickness of individual stratigraphic units.

Keywords: Pre-Carpathian Foredeep, Jurassic, fauna, paleostratigraphy, paleoecology.

\section{Особливості стратиграфічного поширення та палеоекологія юрських двостулкових молюсків Передкарпатського прогину}

\section{I. В. Шайнога, В.В. Карабин}

Львівський національний університет імені Івана Франка, Львів, Украӥна,e-таil: chigvos@ukr.net

\begin{abstract}
Анотація. Передкарпаття - один з найдавніших нафтогазодобувних районів нашої держави, який щораз більше привертає увагу науковців. У Передкарпатському прогині, в межах його Зовнішньої зони, юрські відклади залягають на значних глибинах (до 3000 м.) тому майже всю геологічну інформацію про них ми отримуємо винятково під час вивчення кернового матеріалу відібраного при проведенні бурових робіт. Всебічне і детальне вивчення юрських відкладів Зовнішньої зони Передкарпатського прогину під час проведення геолого-розвідувального буріння у 50 -х роках сприяло відкриттю Коханівського та Судововишнянського нафтових і Рудківського газового родовищ, а також виявити низку нафтогазопроявів. Після відкриття цих великих покладів цікавість до умов утворення та стратиграфічного розмежування юрських відкладів посилилася., Дослідники почали сприймати їх, як перспективний об'єкт для розшуків нафти та газу. У Передкарпатському прогині вони виповнюють єдиний прогин, який має назву - Стрийський юрський прогин, перекритий потужною товщею порід крейди $\mathrm{i}$ неогену. Іхнє геологічне вивчення та стратиграфічне розмежування набуло важливого прикладного і наукового значення, адже стратиграфічні дослідження слугують базою при з'ясуванні історії геологічного розвитку регіону, для виконання тектонічних побудов, реконструкції палеогеографічних та палеоекологічних умов, для зіставлення продуктивних горизонтів та уточнення їхнього стратиграфічного положення, пошуку нових перспективних на вуглеводні об'єктів. Надзвичайно рідкісні знахідки палеонтологічних решток не завжди доброї збереженості не дають змоги однозначно трактувати вік вмісних порід. Через слабку палеонтологічну вивченість та часткову невизначеність у трактуванні геологічної будови цих товщ дотепер не завжди вдається чітко провести стратиграфічне розмежування та корелювати ці утворення. Незважаючи на значний обсяг виконаних нами досліджень, дискусійними є деякі питання щодо повноти їхнього розрізу та наявності в них окремих стратиграфічних
\end{abstract}


підрозділів. В результаті детального і всебічного вивчення нами упродовж багатьох років двостулкових молюсків, знайдених в керні свердловин, пробурених у Зовнішній зоні Предкарпатського прогину, уточнено і підтверджено вік вмісних товщ, та потужності окремих стратиграфічних підрозділів.

Ключові слова: Передкарпатський прогин, юра, фауна, палео, стратиграфія, палеоекологія.

\section{Introduction}

The Pre-Carpathian Foredeep is the complexly built geotectonic structure of the first order which has been formed in the Miocene during orogenesis of the Carpathian geosyncline (on its north-eastern edge). Jurassic deposits, developed in the territory of the Ukrainian Pre-Carpathian region, form the independent structural element - the Stryi Jurassic deflection, filled by the strata of terrigenous, terrigenous-carbonate and carbonate rocks with the thickness of up to 1,000 m (Vyalov, 1950; Burov, Vishnyakov, 1985).

Information obtained during drilling operations in the territory of the Pre-Carpathian Deflection in the areas of Velyki Mosty, Pidluby, Stryi, Sokal, Sudova Vyshnia, Pivnichni Medynychi, Pivnichna Kokhanivka, Boniv, and others allowed others to interpret the spread of Jurassic sediments in western Ukraine. The well revealed a thick layer of Jurassic sediments, the age of which was determined by the finds of foraminifera, mollusks, spores and pollen. On this basis, conclusions were drawn about the wider than expected Jurassic deposits within a single Jurassic depression.

The asymmetric structure of the Stryi Jurassic deflection was determined. Its western and eastern sides differ in thickness, lithological and facial features and rocks' dislocations. The south-western part is composed of a thick layer of intensively dislocated rocks of the
Lower-Upper Jurassic, which are divided into blocks by a system of faults. The north-western part is composed of Oxford-Tithonian rocks, which lie monoclinally and have small thickness. A characteristic feature of the sediments is a gradual increase in the thickness and completeness of the section in the western-southwestern directions. The maximal thickness of Jurassic sediments was recorded near the Krakovetskyi fault (Dulub, 1964; Leshchukh, 1978).

Conformable bedding of the Middle Jurassic deposits on the underlying Lower Jurassic strata has been determined, and it is non-conformably covered by rocks of the Upper Jurassic.

The performed studies (Gavrilishin and Karpenchuk, 1982) made it possible to improve the biostratigraphic basis of the Pre-Carpathians Jurassic sediments, which are generally poor in paleontological finds.

We have tried to investigate more fully and comprehensively some of the controversial issues related to the completeness of the section and the stratigraphic delimitation of the Jurassic strata in the Pre-Carpathian Foredeep. To do this, we used new paleontological finds discovered in the wells of Romanivska-1, Podiltsi-1, Podiltsi-2, Yurivska-1, Yurivska-2 and others (Fig. 1). As a result of the performed researches quite interesting changes in quantitative and species diversity of the revealed and defined paleontological forms are recorded.

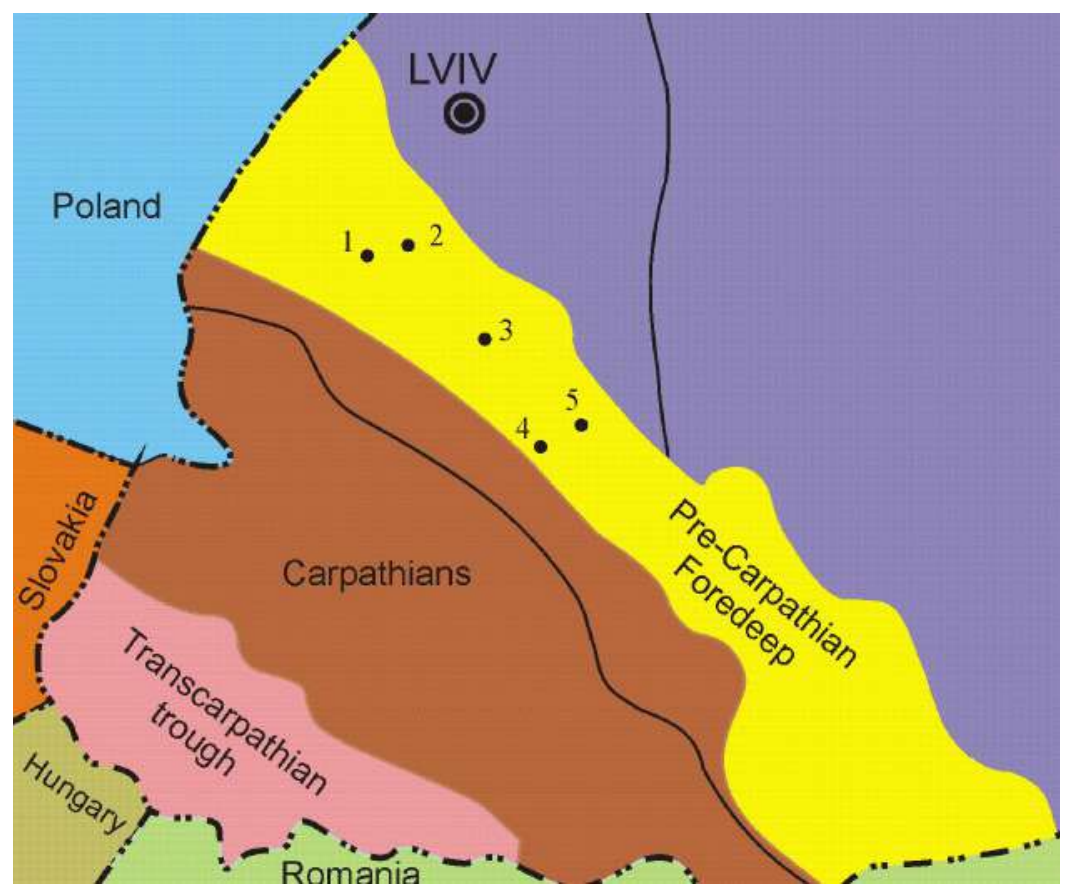

Fig. 1. Schematic map of well locations: 1 - Yurivska-1; 2 - Yurivska-2; 3-Romanivska-1; 4 - Podiltsi-1; 5 - Podiltsi-2. 
The available geological and geophysical material has been analyzed, which is important for the study of the vertical distribution of macrofauna. This is of scientific and applied importance for the study of the stratigraphy of Jurassic (and not only) sediments. Particular attention has been paid to the lithological composition of the host rocks, the patterns of their occurrence and the thickness of the various layers.

\section{Materials and methods of research}

Samples for research were selected during the study of the core material. In total, more than 200 samples with paleontological remains from more than 40 wells were processed. The core material from the following drilling areas was analized: Kokhanivska, Rudky, Bortiatyn, Pivnichni Medynychi, Hrushiv, Lopushna, Dashava, Verbizh, Paryshche, Verchany, Boniv, Karolina, and others (Slavin, Dobrynina, Efimova,
1967; Leshchukh, Bubnyak, 1991). A significant amount of published and fund geological and geophysical material has been studied and analyzed in detail. The performed researches are a fundamental part of the complex estimation of prospects of oil and gas potential of the Pre-Carpathian oil and gas region Jurassic deposits, a scientific basis for carrying out prospecting and geological survey works. They can be used to dissect and correlate well sections in promising areas, as well as to determine or refine the age of stratigraphic intervals and productive horizons (Shainoga, Leshchukh, Hotsanyuk, 2001).

During the monographic study of paleontological material, the terminology and systematics given in the handbook "Fundamentals of Paleontology" (1960, in Russian) edited by A. G. Eberzin have been taken as a basis (Fig. 2).

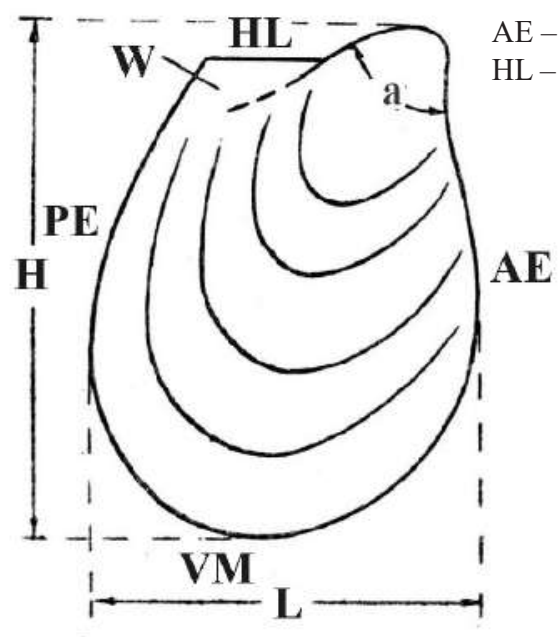

$\mathrm{AE}$ - anterior edge; $\mathrm{VM}$ - ventral (abdominal) margin; $\mathrm{PE}$ - posterior edge; $\mathrm{HL}$ - hinge line; $\mathrm{W}$ - wing; $\mathrm{H}$ - height; $\mathrm{L}$ - length; $\mathrm{a}$ - apical angle.

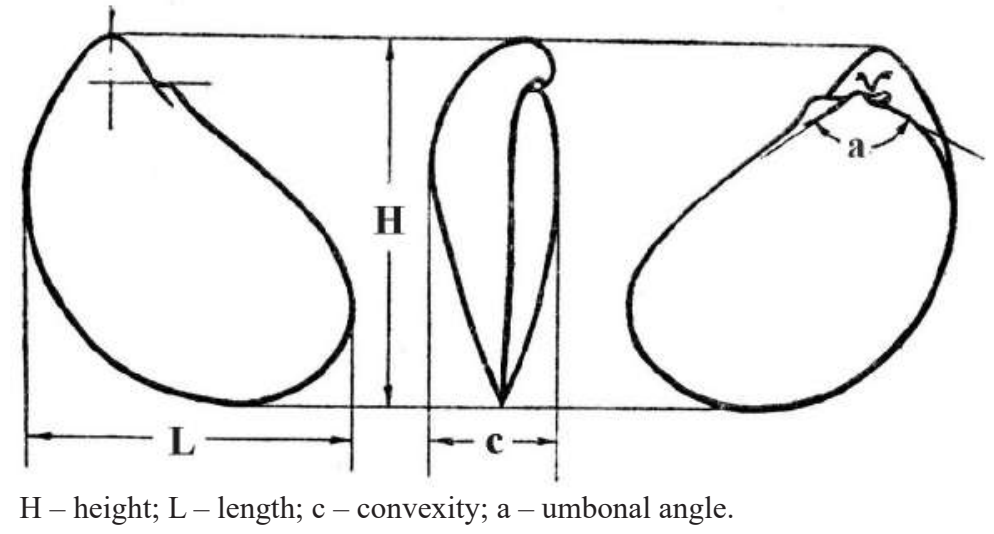

Fig. 2. Scheme of the bivalve mollusk shell structure.

During the research we comprehensively applied lithological and biostratigraphic methods of studying paleontological remains, which were slightly changed and supplemented in accordance with the subject of research, the main tasks and geological features of the region.

We used the lithological method to dissect and compare sediments according to a set of lithological features, described rocks, and distinguished their lithogenetic types. We performed these works taking into account the recommendations set out in many methodological works (Romanov, 1973, etc.). The relative and absolute ages of rocks have been determined in the region, sections have been compared, local lithostratigraphic units have been sorted by age and position relative to stratons of the general stratigraphic scale, and biostratigraphic characteristics of local and general stratigraphic units have been improved.

The biostratigraphic method was used to dissect and correlate sedimentary strata with the remains of paleoorganisms (fossils). We conducted biostratigraphic studies at all stages of stratigraphic study, also clarified the physical and geographical parameters of the paleoenvironment, and supplemented the facial characteristics of sediments (Merklin, 1949; Hecker, 1954).

The subject of research is the remains of paleoorganisms and host sedimentary rocks. Fossils have been studied in two directions that are closely related and are the stages of biostratigraphic research. The core and the interval location of the remains of bivalve molluscs were described in detail at the first (field) stage. At the second (laboratory) stage, we performed a morphological description of the remains of paleoorganisms, determined their species and genus composition by the morphological-comparative method, and analyzed the distribution of the defined forms in the sedimentary strata.

The source material was information on the distribution of fossils in section and laterally. The composition of fossil complexes reflects the structure of bio- 
cenoses and is determined by the degree of evolutionary development of biota, ecological relations between organisms, abiotic environmental factors and taphonomic conditions of burial and fossilization of fossil forms.

\section{Results}

The basis of the comprehensive research was the study of the macrofauna of bivalve mollusks. Diagnosis of shells was based on the study of their shape, size and sculpture. During the species diagnostics, depending on the quality of material preservation, it is not always possible to find all the elements of the external and internal structure. Poor preservation of paleontological material in many cases complicates its diagnosis. It is difficult to determine one or more typical morphological features for each species, because the degree of preservation of the material in each case is very different (Shinoga, 2001).

Preservation of the material is diverse: the remains of bivalve mollusks occur mainly in the form of imprints of internal and external casts, occasionally - whole skeletons. There is a mechanically destroyed material, the bulk of which is the imprints of the valves and a large number of fragments, which is often observed in the host rocks.

Imprints of sashes: Phaenodesmia $\mathrm{cf}$ arzisiensis Rom., - four specimens, Nucula eudorae Orb. - four, N. subovalis Boriss. - three, Leda lacryma Sow. - two, Leda mucronata Sow. - two, Leda acuminata Gold., - one; Cucullaea cucullata Gold. - one, Entolium demissum Phill. - three, E. singulatum Gold. - one, Anisocardia cf. minima Sow. - four, Goniomy recta Pčel. - three, Goniomya sp. - one, Parallelodon sp. nov. - one, Posidonia buchi Roem. - eight, Lima (Plagiostoma) subrigidula Schlippe.- one, Pleuromya tenuistriata Gold. - one, Pleyromya caudata Terg et Jourdy. - one, Nucula jagmanica Sibir. - one, Nucula simetrica Boris. - one, Cucullaea subdecussata Gold. - one, Oxytoma scarburgense Rollier. one, Laternula undulata Sow. - one, Leda acuminata Gold. - one, Parallelodon elongatum Sow. - one.

Internal cores: Pholadomya murchisoni Sow. two, Pholadomya solitaria Mor. et Lyss. - one, Goniomya baysunensis Gold. - three, Astarte cf. orbicularis Sow. - one, Pinna buchi Koech et Dunker. - one, Pleyromya decurtata Phill. - one, Pleyromya balkhanensis Pcel. - one.

Whole skeletons: Astarte pulla Roem. - four.

In most fossils the surface of the fossil is covered with sculpture, in some forms it is clearly expressed, in others the sculptural elements are less clear, they can be clearly seen only under binoculars, on some imprints sculpture is practically absent.

Radial sculpture: Cucullaea cucullata Gold., Goniomya baysunensis Gold., Pholadomya murchi- soni Sow., Pholadomya solitaria Mor. et Lyss., Entolium demissum Phill., E. singulatum Gold., Lima (Plagiostoma) subrigidula Schlippe., Pinna buchi Koech et Dunker., Leda lacryma Sow., Leda mucronata Sow.

Concentric sculpture: Pleuromya tenuistriata Gold., Pleyromya caudata Terg et Jourdy., Pleyromya decurtata Phill., Pleyromya balkhanensis P cel., Nucula eudorae Orb., N. subovalis Boriss., Astarte pulla Roem., Anisocardia cf. minima Sow., Posidonia buchi Roem., Leda acuminata Gold., Phaenodesmia cf. arzisiensis Rom.

Radial-concentric: Parallelodon sp. indet.; Divaricate: Goniomy recta Pčel., Goniomya baysunensis Gold., Goniomya sp.

Found remains of bivalve mollusks vary in shape and size. In terms of shape, most specimens have an oval-elongated shell. Oval: Pleyromya balkhanensis Pcel., Pleuromya tenuistriata Gold., Nucula subovalis Boriss., Nucula eudorae Orb., Nucula jagmanica Sibir., Nucula simetrica Boris. Round-rhombic: Cucullaea cucullata Gold. Oval-elongated: Pleyromya caudata Terg et Jourdy., Pleyromya decurtata Phill., Goniomya baysunensis Gold., Leda lacryma Sow., Leda mucronata Sow., Phaenodesmia cf. arzisiensis Rom., Goniomya sp. Round: Lima (Plagiostoma) subrigidula Schlippe., Goniomy recta Pč el., Posidonia buchi Roem., Astarte pulla Roem., Anisocardia cf. minima Sow. Round-triangular: Pholadomya murchisoni Sow., Pholadomya solitaria Mor. et Lyss., Parallelodon sp. indet., Leda acuminata Gold., Entolium demissum Phill., E. singulatum Gold. Coneshaped: Pinna buchi Koech et Dunker. (10\%).

Large: Cucullaea cucullata Gold., Entolium demissum Phill., E. singulatum Gold., Pholadomya murchisoni Sow., Pholadomya solitaria Mor. et Lyss., Goniomy recta Pčel., Goniomya baysunensis Gold., Goniomya sp., Leda acuminata Gold., Parallelodon sp. indet., Posidonia buchi Roem., Pinna buchi Koech et Dunker., Lima (Plagiostoma) subrigidula Schlippe., Pleuromya tenuistriata Gold., Pleyromya caudata Terg et Jourdy., Pleyromya decurtata Phill., Pleyromya balkhanensis Pcel., Oxytoma scarburgense Rollier.

Medium: Nucula eudorae Orb., Anisocardia cf. minima Sow., Cucullaea subdecussata Gold.

Small: Astarte pulla Roem., Leda lacryma Sow., Leda mucronata Sow., Phaenodesmia cf. arzisiensis Rom., Nucula subovalis Boriss. Nucula jagmanica Sibir., Nucula simetrica Boris.

According to the degree of sashes convexity:

Very convex: Leda mucronata Sow., Cucullaea cucullata Gold., Pholadomya murchisoni Sow., Pholadomya solitaria Mor. et Lyss., Goniomy recta Pčel., Goniomya baysunensis Gold., Goniomya sp., Pinna buchi Koech et Dunker., Lima (Plagiostoma) 
subrigidula Schlippe., Pleyromya caudata Terg et Jourdy., Pleyromya decurtata Phill., Pleyromya balkhanensis Pce1.

Anisocardia cf. minima Sow., Leda lacryma Sow., Posidonia buchi Roem., Pleuromya tenuistriata Gold., Parallelodon sp. indet., Astarte pulla Roem., Phaenodesmia cf. arzisiensis Rom., Nucula eudorae Orb., N. subovalis Boriss., Nucula jagmanica Sibir., Nucula simetrica Boris., Cucullaea subdecussata Gold., Oxytoma scarburgense Rollier.

Flat: Entolium demissum Phill., E. singulatum Gold.

The material is unsorted: there are shells of different sizes in one interval. The forms are oriented horizontally to the bedding plane, mainly convex upwards. There are accumulations of sashes (well Romanivska-1) or separate scattered sashes (Yurivska-1, Yurivska-2, Podiltsi-1, Podiltsi-2). A large number of shell detritus is represented by fragments of different sizes, which are located in the rock in individual spots. Findings of forms are confined to the middle part of interbeds (Shaynoga, Leshchukh, 2002).

The largest number of specimens was found in the lower part of the section, and in the middle and upper ones only remains of individual forms are available.

Imprints of the right or left sashes and individual cores predominate among the finds, with casts more common in the upper part of the section and imprints of the sashes - in the lower part. In most cases, these are imprints of the left or right sashes, which lie convex upwards.

Most of the fauna buried in aleurolites retains its shape, because during diagenesis the volume of the substance that fills the shell is almost not reduced, and the shell is not deformed. Organic remains are better preserved in more solid and denser rocks during mechanical deformations. An important factor for conservation is also the rate of sedimentation.

Selected types of mollusk burial are typical for certain hydrodynamic conditions. They can be used as indicators of changes in the aquatic environment during sedimentogenesis, which is a major factor in the formation of taphocenoses and various forms of preservation.

Stenogaline forms have been identified among the found fossils, in particular, the genus Leda, which was studied by R. L. Merklin (Merklin, 1949). According to him, it is a benthic form, the habitat of which was a salt basin (salinity at least $28 \%$ ), the conditions were calm, the soil was soft, representatives of this genus could tolerate oxygen deficiency.

Representatives of the genus Nucula are sedentary; they are shallowly buried in the bottom sediment and can move in it. These are mainly inhabitants of the soft sandy-clay soils of the sublittoral, most populations are observed at a depth of up to $90 \mathrm{~m}$. These are fairly eurythermal organisms, living in warm temperate and cold reservoirs.

Most of the found forms are stenogaline normal-marine individuals $(70 \%)$, some of them occur in desalinated areas of the basin, in particular Entolium demissum Phill., Entolium singulatum Gold. (25\%), and subsaline water areas, such as Astarte pulla Roem. (5\%).

The temperature of the sea basin is important for determining the paleoecological living conditions of mollusks. The vast majority of forms are stenothermic (tropical and subtropical): Posidonia buchi Roem., Pholadomya murchisoni Sow., Pholadomya solitaria Moriss et Lycett. (50\%), part of mollusks - stenothermal boreal: Astarte pulla Roem. and stenothermal arctic: Nucula subovalis Gold., Nucula cf. eudorae Orb., Nucula simmtrica Boriss., Nucula jagmanica Sibir., Leda lacryma Sow., Leda mucronata Sow., Cucullaea cucullata Gold., Cucullaea subdecussata Gold. (Quenstedt, 1858; Roemer, 1911).

We found the fauna in narrow intervals of the section with the thickness from the first meters to $10 \mathrm{~m}$. The number of fossil remains is insignificant, and they almost do not form mass accumulations. They are placed unevenly in the vertical section.

The genus and species composition of the fauna of bivalve molluscs defined by us is represented mainly by representatives of the following orders: Desmodonta (desmodonts) - genera: PHOLADOMYA (Pholadomya cf. murchisoni Sowerby, 1827, Pholadomya solitaria Morris et Lycett, 1850, Goniomya recta Pčelincev, 1927, Goniomya baysunensis Borissjak, 1910, Goniomya sp.); PLEUROMYA (Pleuromya balkhanensis Pčelincev, 1928, Pleuromya decurtata Phillips, 1829, Pleuromya coudata Terquem et Jourdy, 1869, Pleuromya tenuistriata Goldfuss, 1836); LATERNULA (Laternula undulata Sow., 1819); Anisomyaria (anisomyarian) - genera: OXYTOMA (Oxytoma, Me ek, 1864, Oxytoma scarburgense Rollier, 1914), PINNA (Pinna buchi Koch et Dunker, 1837), POSIDONIA (Posidonia(Bositra) buchi Roemer, 1836), LIMA (Lima (Plagiostoma) subrigidula Schlippe, 1888), ENTOLIUM (Entolium demissum Goldfuss, 1834, Entolium singalatum Goldfus s, 1836); Taxodonta (taxodonts) - genera: PHAENODESMIA (Phaenodesmia arzisiensis Romanov 1973), LEDA (Leda lacryma Sowerby, 1824, Leda mucronata Sowerby, 1824, Leda acuminata Gold., 1826), NUCULA (Nucula subovalis Goldfuss, 1836, Nucula eudorae Orbigny, 1847, Nucula jagmanica Sibir, 1960, Nucula simetrica Borissjak, 1904), CUCULLAEA (Cucullaea cucullata Goldfuss, 1837, Cucullaea subdecussata Gold., 1838), PARALLELODON (Parallelodon sp indet., Parallelodon elongatum Sow., 1824) 12 species; Heterodonta (heterodont) - genera: ASTARTE 
(Astarte pulla Roemer, 1836, Astatre cf. orbicularis Sow., 1812), ANISOCARDIA (Anisocardia cf. minima Sowerby, 1837) (Table 1).

Taking into account the significance of each paleontological find, as well as the fact that information on the composition, number and degree of preservation of mollusks was obtained during a detailed study of the core, we compared our materials with lithogenetic types and facies of potential oil and gas deposits of other regions. This approach makes it possible to obtain a comprehensive lithological-facial and paleontological characteristics of sediments - the main source material for further research and constructions (Koch et Dunker, 1837).

Table 1. Stratigraphic distribution of Jurassic bivalve mollusks within the Pre-Carpathian Foredeep

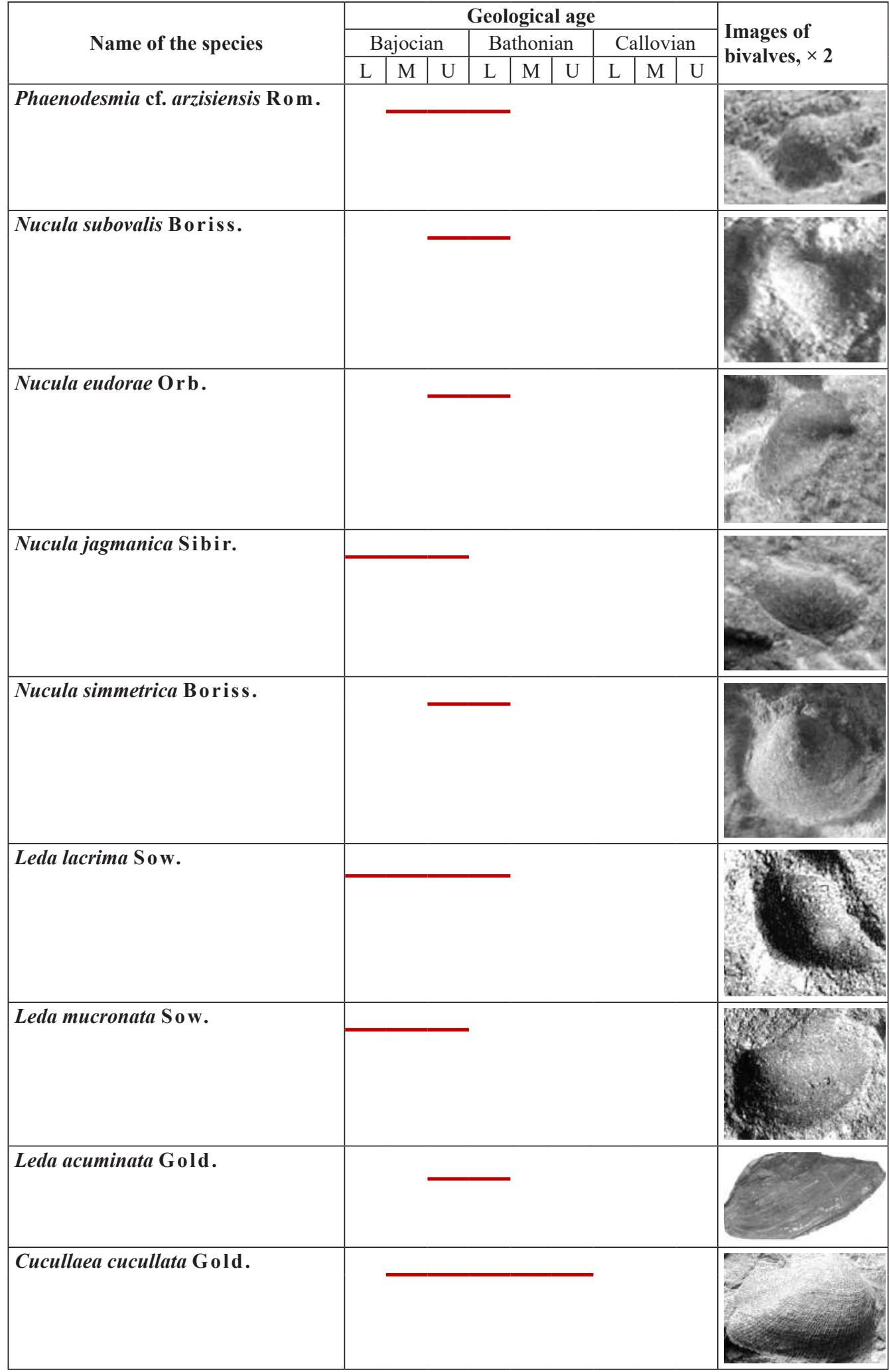


Continuation of Table 1

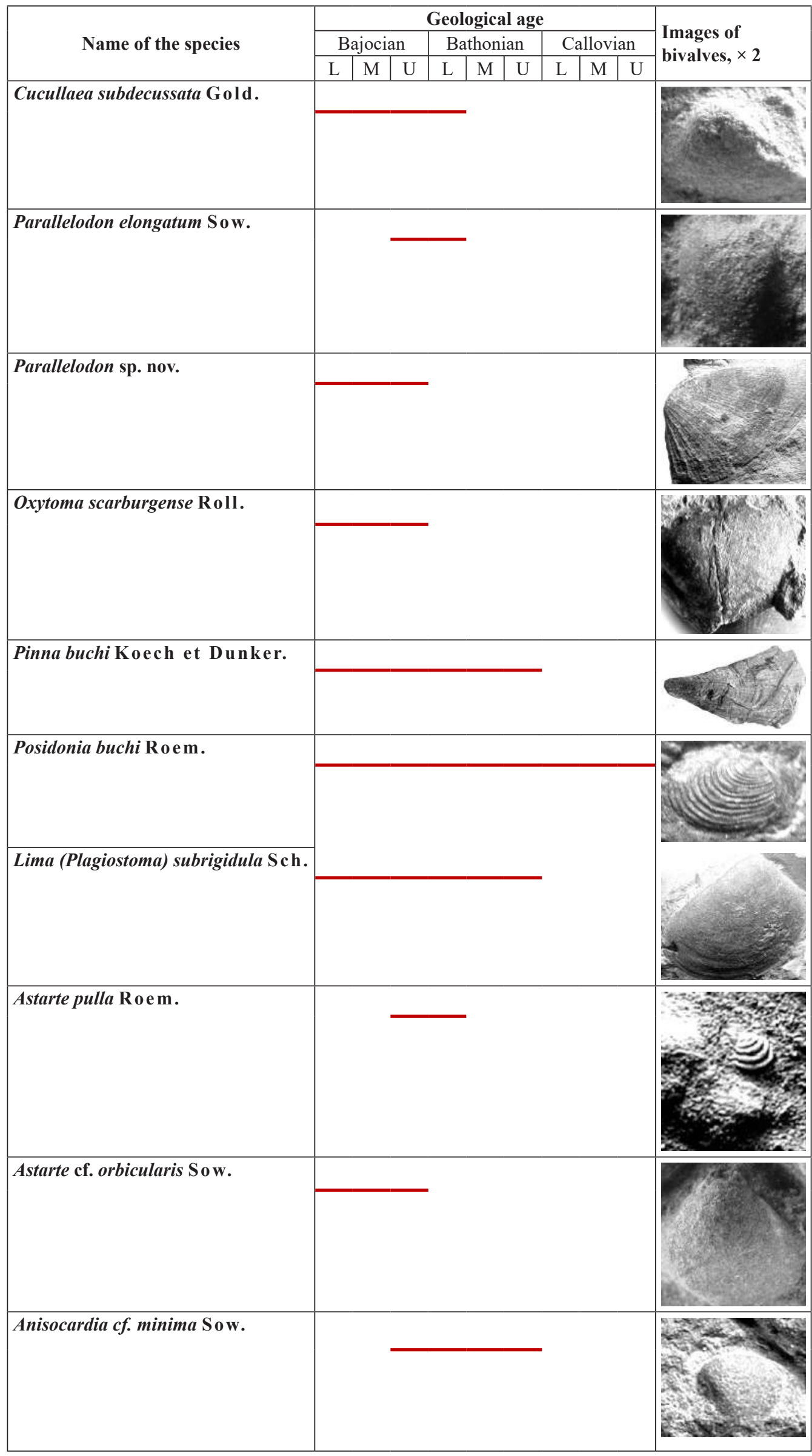


Continuation of Table 1

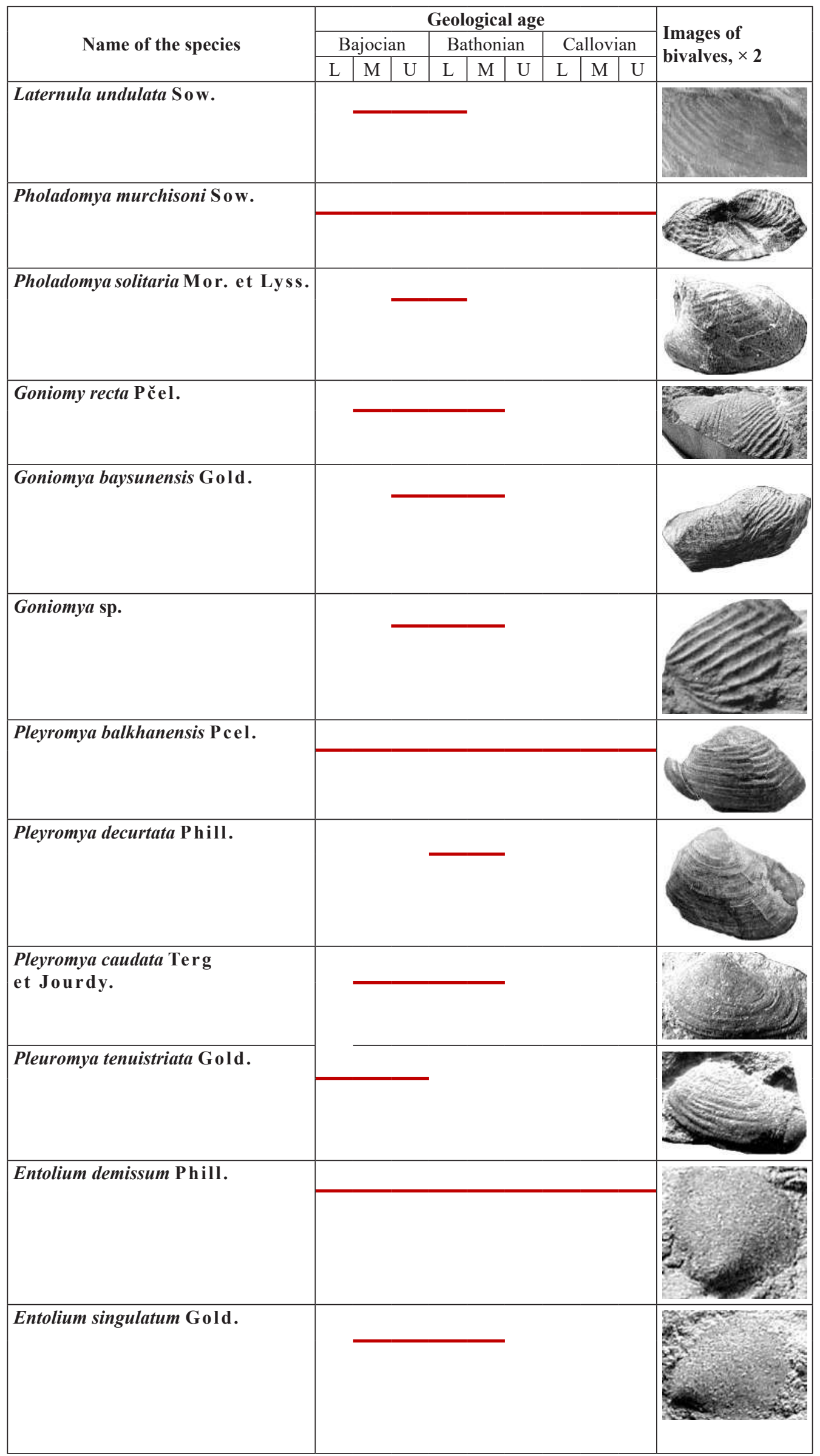


The complex of rocks in which Jurassic macrofauna has been found most often is represented by grey to black non-calcareous hard argillites and fine-grained quartz sandstones. There are greenish-grey non-calcareous aleurolitess in some places, as well as grey non-calcareous thin-layered mica quartz sandstones. Sometimes one can find calcareous argillites with organogenic detritus. Small charred plant remains and pyrite grains are found throughout the section (Fig. 3).

The results of our studies of bivalve mollusks from Jurassic deposits of the Pre-Carpathian Foredeep Outer zone indicate the following: the forms we found have a relatively narrow range of stratigraphic distribution
(Bajocian-Bathonian, Callovian), so they reliably prove the wide development of the Middle Jurassic deposits in the zone and allow to perform their much more detailed stratification and correlation. The species composition of the bivalve molluscs we have identified indicates a direct or very close connection between the PreCarpathian Jurassic and the Pre-Dobrogea sea basins.

The distribution of fauna in the Jurassic Sea was mainly due to the presence of different facial zones. The bionomic features of these zones contributed to the formation of a complex of fauna that adapted to certain conditions.

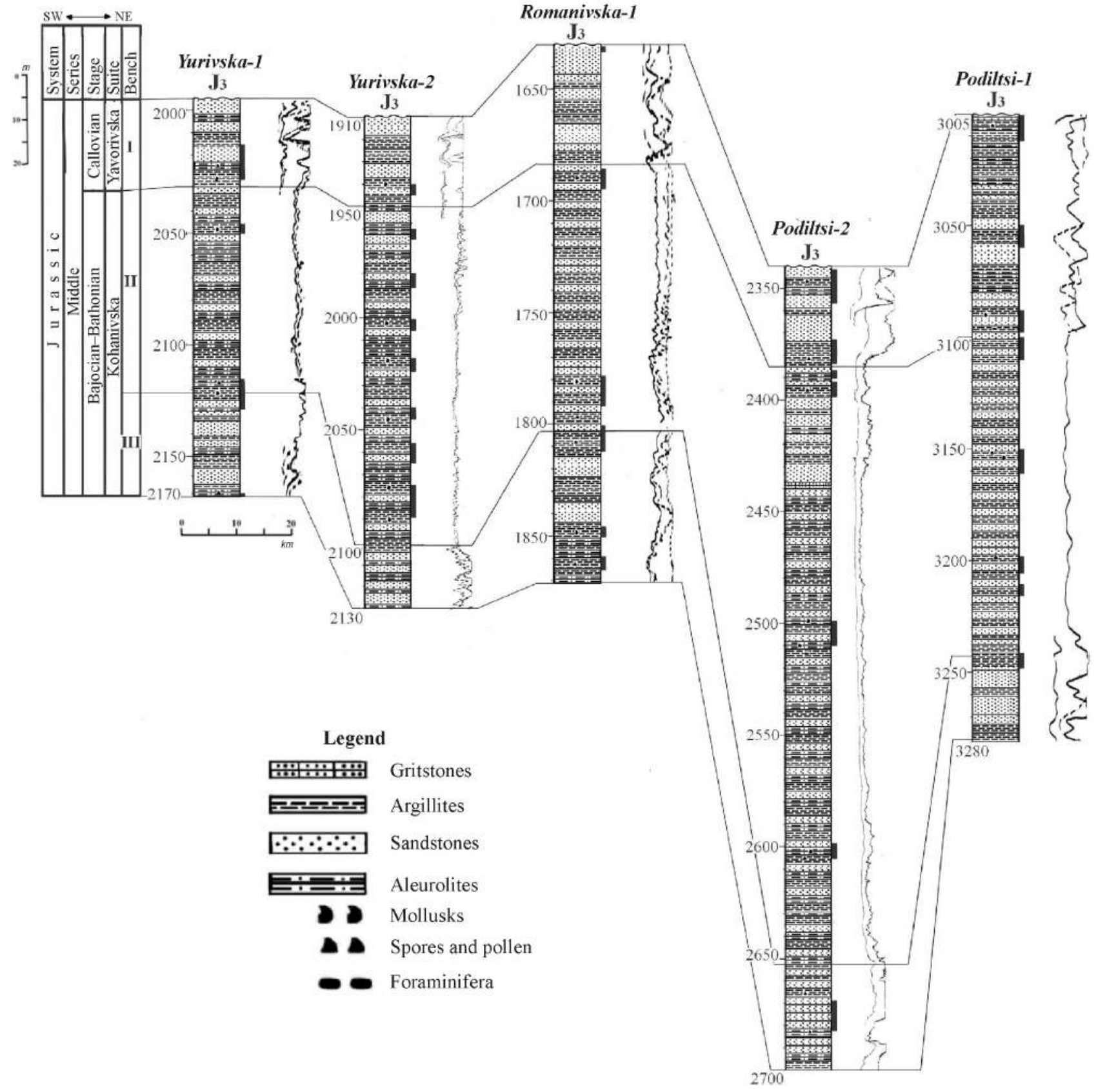

Fig. 3. Geological sections of the studied wells. 


\section{Conclusions}

On the basis of a comprehensive study of bivalve molluscs, the biostratigraphic characteristics of the Jurassic stratum of the Pre-Carpathian Foredeep Outer zone have been significantly supplemented. The bivalve mollusks from Jurassic sediments were identified and monographically studied for the region first. Peculiarities of their stratigraphic distribution in the region are revealed. There are two stratigraphic levels of maximal distribution of mollusks, which differ in the saturation of fauna, its species diversity and orientation in the section. Bivalve mollusks are in the lower and upper parts of the section.

We paleontologically substantiated and confirmed the allocation of Bajocian, Bathonian and Callovian stages and defined their limits. The biostratigraphic characteristics of the studied strata have been improved, and it has also been proved that there was no significant break in the sedimentation at the Bathonian-Callovian boundary. The conditions of sedimentogenesis during the Middle Jurassic have been reproduced.

The lithostratigraphic delimitation of the Jurassic stratum with the allocation of two secondary lithostratigraphic subdivisions has been detailed, and their strati-

\section{References}

Agasiz, L., 1840. Etuded critiques sur les mollusques fossiles. Monographie des Myes. 123-187.

Alth, A., 1881. Wapien Nizniowski and jego skamieliny. Sb. Acad. Um. W Krakowie. 6, 26-37.

Burov, V.S., Vishnyakov, I.B., et al., 1985. K voprosu o litostratygraficheskom podrazdelenii i usloviakh nakopleniia yurskih otlozhenii Predkarpatia i VolynoPodolia. [On the issue of lithostratigraphic subdivision and the conditions of accumulation of Jurassic sediments in Ciscarpathia and Volyno-Podol]. 4, 130-136. (In Russian).

Derzhavna geologichna karta Ukrainy. 2004. Mashtab 1: 200,000, [State geological map of Ukraine, scale 1: 200,000]. Kyiv: Ministry of Environment and Natural Resources of Ukraine (In Ukrainian).

Dulub, V.G., 1964. Yurskie pestrotsvetnyie obrazovaniia Volyno-Podolskoi okrainy Russkoi platformy. [Jurassic variegated formations of the Volyn-Podolsk margin of the Russian platform]. 9, 101-105. (In Russian).

Gavrilishin, V.I., Karpenchuk, Y.R., 1982. Nakhodki makrofauny $v$ novyh tipah yurskih razrezov Predkarpatskoho progiba. [Finds of macrofauna in new types of Jurassic sections of the Ciscarpathian trough]. Kiev: NAS of Ukraine, 34-35. (In Russian).

Glushko, V.V., 1968. Tektonika i neftegazonosnost Karpat i prilegaiushchih progibov. [Tectonics and oil and gas content of the Carpathians and adjacent troughs]. Moscow, 259 p. (In Russian). graphic position (age) has been substantiated. The first subdivision is distinguished in the upper, larger part of the investigated section. It has a thickness of up to $200 \mathrm{~m}$, and is composed of a thin rhythmic layering of sandstones, aleurolites and argillites, which are evenly represented in the section. Numerous bivalve mollusks that do not form accumulations have been identified in it. Among them, two guiding taxa for the Bathonian stage have been identified: Goniomya baysunensis Borissjak, Pleuromya decurtata Phillips. The second subdivision has been distinguished at the bottom of the stratum; it has a thickness of up to $80 \mathrm{~m}$ and is composed of a coarse alternation of sandstones, argillites and aleurolites benches. The distribution of rocks lithotypes here is different than in the first subdivision: sandstones form benches up to $10 \mathrm{~m}$ thick, between which there are layers of aleurolite-argillite composition with a thickness of 2-3 m. Numerous bivalve mollusks of different categories (background, characteristic and guiding) which form accumulations have been identified herein. Among them, two taxa, typical only for the Bajocian, were found: Astatre orbicularis Sow., Pholadomya solitaria Morris et Lycett.

Greppin, E., 1896. Description des fossiles du Bajocien superieur des Environa de Bale. Mem. Soc. paleont. 25-24.

Hecker, R.F., 1954. Nastavlenie dlia issledovanii po paleoekologii. [Manual for Research in Paleoecology]. Movcow: Nedra, 15-34. (In Russian).

Koch et Dunker., 1837. Beiträge zur Kenntniss des norddeutschen Oolitengebildes und dessen Versteinerungen. Braunschweig, $76 \mathrm{p}$.

Leshchukh, R.Y., 1978. O vremens proiavleniia vulkanizma yugo-vostoka Ukrainskih Karpat. [About the time of manifestation of volcanism in the southeast of the Ukrainian Carpathians]. 51, 12-17. (In Russian).

Leshchukh, R.Y., Bubnyak, I.M., 1991. Moliusky serednioyurskykh vidkladiv Zovnishnioi zony Peredkarpatskoho prohynu. [Molluscs of the Middle Jurassic species of the Outer zone of the Pre-Varpathian Foredeep [Paleontological Zbirnyk] 28, 30-34. (In Ukrainian).

Merklin, R.L., 1949. K poznaniiu paleoekologii molliuskovoi fauny verkhnetarkhanskih glin Kerchenskogo poluostrova. [To the knowledge of the paleoecology of the mollusk fauna of the Verkhnetarkhan clays of the Kerch Peninsula [Publishing house. AN SRSR] 15 p. (In Russian).

Moryc, W., 1961. Budowa geologiczna rejonu Lubaczowa. Rocznik Polskiego Towarzystwa Geologicznego 31, 47-83.

Quenstedt, A., 1858. Der Jura. Tubingen, 552 p. 
Roemer, J., 1911. Die Fauna der Aspidoides Schichen von Lechstedt bei Hildesheim. Hannover, 76-140.

Romanov, L.F., 1973. Yurskie morskie dvustvorchateie molliuski mezhdurechia Dnestr-Prut [Jurassic marine bivalves of the Dniester-Prut interfluve]. Chisinau: Shtiintsa, 227 p. (In Russian).

Shainoga, I., Leshchukh, R., Hotsanyuk, H., 2001. The Ukrainian Carpathians autochton - a new oil and gas exploration object [Nowe metody i technologie naftowej, wiertnictwie, eksploatacji otworowej i gazownictwie] Krakow: 41-45.

Shaynoga, I., Leshchukh, R., 2002. Novi znakhidky dvostulkovykh moliuskiv u yurskykh vidkladakh Peredkarpatskoho prohynu [New henchmen of twostalked molluscs in the Jurassic specimens of the Precarpathian Progin [Paleontological collection] 34, 47-54. (In Ukrainian).
Shinoga, I., 2001. Biostratyhrafichna kharakterystyka serednioiurskykh vidkladiv u sverdlovyni Romanivska-1 (Peredkarpatskyi prohyn) za moliuskamy [Biostratigraphic characteristics of Middle Jurassic specimens near Sverdlovina Romanivska-1 (Precarpathian foredeep) for molluscs [Paleontological collection] 33, 120-123. (In Ukrainian).

Slavin, V.I., Dobrynina, V.Y., Efimova, N.A., 1967. Novyie dannyie o yurskih otlozheniiah Sovetskih Karpat [New data on the Jurassic deposits of the Soviet Carpathians [Materials of the VIII Congress. KBGA] Belgrade, T. 1. 347 p. (In Russian).

Vyalov, O.S., 1950. Vremia obrazovaniia flishevogo troga Karpat i kharakter porod ego fundamenta. [Time of formation of the Carpathian flysch trough and the nature of its basement rocks]. 410-414. (In Russian). 